\title{
WHAT ARE WORKERS DOING ABOUT ELECTRONIC SURVEILLANCE IN THE WORKPLACE?
}

\author{
An Examination of Trade Union Agreements in Canada
}

\author{
Vincent Mosco and Simon Kiss \\ Mosco is Canada Research Chair in Communication and Society, moscov@mac.com and Kiss \\ is a Ph.D. student in Political Studies, at Queen's University, Kingston, Ontario, Canada
}

\begin{abstract}
Information and communication technology has deepened the problem of workplace surveillance by expanding the capacity to measure and monitor worker activity. Partly because of inadequate government attention to privacy protection and partly because the government itself has used security concerns to overturn privacy protections, civil society organizations and movements have increasingly taken an active role to secure the right to privacy. This paper assesses the extent to which trade unions in Canada have made privacy a sufficiently serious concern to see that privacy protections are incorporated into collective agreements. It assesses the progress made since Bryant's 1995 study which found practically no reference to electronic privacy protection in Canadian agreements. The paper concludes by identifying best practice language for unions negotiating to incorporate privacy, surveillance, and monitoring language in their collective agreements.
\end{abstract}

\section{INTRODUCTION}

The growth of information and communication technology has deepened the problem of workplace surveillance by expanding the capacity to measure and monitor worker activity (Head, 2003; Parenti, 1999; Wallace, 2004). Although there is some research on the extent of this challenge to privacy in the workplace, there is little research on what workers and particularly their unions are doing about it. 
Traditionally, privacy and privacy protection have been deemed to be the proper role of the state and this has been embodied in laws and regulations governing the use of consumer and citizen data (Bennett, 2003). But governments in North America have generally ignored worker concerns and those in Europe have been slow to respond. Specific European privacy laws, supported by Europe's unions and opposed by businesses, are in the works. The European Commission is consulting on a new law on the protection of workers' personal data that will cover data about employees, including email, internet use and health records as well as issues of consent, drug and genetic testing, and monitoring and surveillance. A few jurisdictions have put in place workplace surveillance legislation. A notable example is the Australian state of New South Wales which established a Workplace Surveillance law in 2005 making it illegal for employers to engage in covert surveillance of emails and web sites, or the use of tracking devices without a court order. International bodies like the International Labour Organization have issued guidelines on elements of surveillance in the workplace particularly on the use of worker data and records. (International Labour Organization, 1997)

Partly because of inadequate government attention to this area and partly because governments themselves have used security concerns to overturn privacy protections, civil society organizations and movements have increasingly taken an active role to secure the right to privacy (Shane, 2004) These include established civil rights organizations like the American Civil Liberties Union (ACLU, 1998) and groups specifically organized around information technology issues like the Electronic Privacy Information Centre in the U.S. and Privacy International in the U.K. (EPIC, 2004; Rotenberg and Laurant, 2004).

We are beginning to observe some attention to privacy protection in collective bargaining agreements (Findlay and McKinlay, 2003). But developments in this area are slow. The shadow of $9 / 11$ has darkened efforts to protect worker privacy in the United States (Bloom, Schachter, and Steelman, 2003; King, 2003). The situation is slightly better in Europe. According to a 2003 report on the European situation, "there is generally little reference in collective bargaining to the issue of protecting privacy at the workplace, either in general or in relation to the use of e-mail and the internet. This is especially true of bargaining at multi-employer level, and where joint regulation of this matter exists, it generally occurs at company level, either through agreements or through the exercise of the codetermination rights of works councils or other workplace employee representatives." (European Industrial Relations Observatory, 2003: 23) 
Notable exceptions include Belgium where national collective agreements provide protections for workers' private lives in the areas of electronic online communications, data and video monitoring. In Norway, the central 'basic agreement' between the Norwegian Confederation of Trade Unions and the Confederation of Norwegian Business and Industry contains a supplementary agreement stipulating a range of conditions under which monitoring and control measures may be implemented by the employer, focusing on the principles of objectivity, proportionality, and universal applicability. The agreement calls for discussion of such measures prior to implementation but negotiations are not required. Workers are also expected to be notified of new surveillance measures prior to their execution and union representatives are also expected to be involved in consultations on the implementation of new practices that might affect member privacy. Measures may be deemed unlawful by the Labour Court, but it is assumed that the agreement does not apply in cases where there are suspicions of criminal acts such as fraud or theft.

Along the same lines, in 2001 the Confederation of Danish Trade Unions and Danish Employers' Confederation agreed that any new surveillance arrangements in the workplace have to be made public at least two weeks in advance of their implementation. Also in Denmark the Union of Commercial and Clerical Employees signed an agreement with Danish Commerce and Service, an employer's organization that serves as a model for companies seeking to establish a policy on employee use of email. In the Netherlands, the collective agreement covering the public transport sector has an annex containing a model privacy code and several collective agreements in the Netherlands protect workers' privacy when they report absent due to illness. Workers in this country also benefit from a law requiring the establishment of Works Councils in all businesses employing more than 35 workers because electronic surveillance cannot take place without the approval of the local Works Council. Some collective agreements in Italy refer to the need to adhere to data protection legislation and especially to the need to protect sensitive personal information about employee health. The Austrian Union of Salaried Employees reports on numerous local collective agreements dealing with relevant privacy issues in all sectors. In France, "information charters" have been put in place with works councils and other employee organizations. The Renault group's 2001 charter provides a model for the use of information resources in the workplace. Finally, Spain has pioneered in collective agreements, particularly in the banking sector, on trade union use of company computer networks for communicating with members and companies, like Ericsson and Barclays Bank SA have agreed to respect the privacy of such communications. (European Industrial Relations 
Observatory, 2003) There is less to report from the UK but the Trade Union Congress and Unison, the largest union in the UK representing public service employees, have been active in promoting greater sensitivity to workplace privacy issues and has proposed model policies. (Hazard's Magazine, 2004)

This paper assesses the extent to which trade unions in Canada have made privacy a sufficiently serious concern to see that privacy protections are incorporated into collective agreements. It does so by drawing on two research projects. The first, The Surveillance Project, is a broad analysis of the global problem of surveillance led by a team of scholars at Queen's University, and the second is a project on Trade Unions and Convergence in the Communications Industry based at Queen's and Carleton Universities.

Specifically, the paper reports on a content analysis of existing Canadian collective agreements to determine the extent to which privacy has been recognized by trade unions, to examine which sectors, industries or individual unions have incorporated surveillance protection into their collective agreements, and to identify specific models of collective agreement clauses. The normative object of the study is to produce a "bestpractices" model for Canadian unions facing surveillance in the workplace.

The content analysis grew out of a series of interviews with people involved with these issues and the primary data-set consists of collective agreements stored in the Negotech database, maintained by the Canadian federal department of Human Resources Development. This database contains a stratified random sample of Canadian collective agreements under both provincial and federal labour law. The data set encompasses both English and French language agreements. These searches revealed just 76 collective agreements with clauses dealing with electronic surveillance and monitoring. Following a discussion of why so few collective agreements contain surveillance clauses, the paper presents a breakdown of these agreements by sector and union and a discussion of recurrent patterns.

The paper found that unions situated in the "knowledge worker" sector, particularly those representing higher education and government employees, are most substantially represented among the unions with privacy language. Moreover, they have the strongest and clearest restrictions against electronic monitoring and surveillance. The paper also found a very wide range of clauses, some of which contain outright prohibition of all forms of electronic monitoring and surveillance, others call for adjudication of the issues by workplace committees, while the weakest feature explicit recognition by the 
union that the employer has all rights to use any forms of electronic monitoring when and where it wishes. Additionally, the paper notes the inclusion of clauses which commit the employer to a level of electronic monitoring in the interests of employee safety. This finding supports the general contention put forward by Lyon $(1994,2001)$ that surveillance in contemporary society contains both negative features as well as positive ones such as security and convenience. The paper concludes by identifying best practice language for unions negotiating to incorporate privacy, surveillance, and monitoring language in their collective agreements.

\section{THE PROBLEM}

Electronic surveillance is becoming a common practice in Canadian workplaces. Three recent examples demonstrate the conflicts that can arise over the introduction of technological surveillance practices. In December 2004, a CN railway employee in Winnipeg discovered surveillance cameras in the workplace, brought them to the attention of the union and management and was subsequently fired. In September 2004, the Federal Privacy Commissioner ruled in that an internet service provider's practice of monitoring employees' behaviour with webcams violated privacy rights. Finally, according to media reports, after a group of financial experts left the Canadian Imperial Bank of Commerce, their former employer launched legal action arguing that they had breached contractual obligations prior to severing their employment ties to the bank. As evidence, they put forward intercepted electronic communications from the employees.

Unions represent an important, but often overlooked, element of workplace surveillance practices. They are often the only recourse workers have to protect their privacy from intrusion. Canadian worker organizations are certainly aware of the problem. In fact, the Canadian Labour Congress, the primary federation of Canadian trade unions, has a policy dating from 1999 that calls for strong protections of worker privacy. But the recommendation is entirely focused on a legislative rather than a collective bargaining strategy: "Herefore be it resolved that the Canadian Labour Congress, in conjunction with our social partners, lead a campaign for federal and provincial privacy legislation applying to all workers and workplaces which includes the principle of meaningful consent, accountability, transparency, security, finality (i.e. use only for the purpose indicated), non-intrusiveness and other protections with respect to all personal data collecting, processing and use during a worker's hiring and 
course of employment." (http:/home.clc-ctc.ca/policies/en/rights/civil \%20 liberties civil\%20rights/de14 99 privacy law.htm)

A number of questions arise: how are unions currently addressing electronic surveillance practices in collective agreements? What is potential "best practices" language for unions to model? What patterns are identifiable in union responses to growing surveillance? This paper seeks to answer these questions starting with the expectation that it would find collective agreements containing surveillance language in the information sector of the economy because it contains more highly educated "knowledge" workers who are more likely to be performing communications and language-related tasks. Moreover, evidence from Europe suggests that where collective agreements contain language protecting workers from employer surveillance and permitting worker use of company computer systems for union business, these are invariably in the communication and information sectors (e.g. Telefonica in Spain, IBM in Italy, and France Telecom). (Aranda, 2002)

\section{LITERATURE REVIEW}

Although thee is some literature on what people are doing about electronic surveillance (Marx, 2003), in much of the general literature on surveillance in the workplace, the role that unions can play is overlooked or neglected entirely. In The Soft Cage, Michael Parenti (2003) dedicates one chapter to the fact of surveillance practices in contemporary workplaces. $\mathrm{He}$ links surveillance practices in the workplace with the principles of Taylorism. Remedies, for Parenti, lie in "regulation, legal limitations and a properly enforced reverse surveillance in which corporations are subjected to the gaze of critics...." (p.150) These remedies again leave out the role that unions can play in restricting surveillance through collective agreements.

Wallace (2004) writes that companies monitor their workplaces through authentication processes, desktop monitoring, the use of location-aware devices, video technologies, and by using "smart" objects which are equipped to communicate with networks and transmit information. The reasons behind surveillance practices range from issues of legal liability to security concerns over leaks to worries about productivity and "cyberslacking." She also emphasizes growing social acceptance of surveillance practices in the wake of the September $11^{\text {th }}$ terrorist attacks. "The notion that it is better to let ten guilty people go free than to convict one innocent person has given way to a heightened desire for security and for greater protection against the horrible acts that any one of those ten 
people might do - even if they have done nothing illegal yet....Now, most people would welcome a highly sophisticated video surveillance system that could spot terrorists in an airport or at the Super Bowl." (p.245)

Bryant (1995) directly addressed electronic surveillance in Canadian workplaces and she is among the few scholars who have emphasized the role that unions could play in protecting employee privacy rights, noting the general weakness of statutory and other constitutional protection for the workplace. The reaction of Canadian unions, however, has been decidedly limited. Bennett (2003) argues that the rise of mobile technologies enabling the creation of mobile workforces - has challenged existing privacy policy instruments to ensure a level of privacy in the workplace. Bennett notes that there is a range of instruments with which issues of privacy and workplace monitoring can be addressed: policy, regulatory, self-regulatory, technological. Beyond a general recognition of the role that they can play in bargaining for privacy rights, there is little attention paid to the role of unions and collective agreements.

A symposium was recently held on the issue of workplace surveillance and the results were published in the Journal of Labor Research Vol. 24 (2). Townsend and Barnett (2003) outlined the excessive levels of intrusion into workplace privacy and emphasized the importance that unions have in ensuring the protection of workers' rights. They cited a survey conducted by the AFL - CIO in which surveyed employees expressed overwhelming support for privacy protection in the workplace. Nolan (2003) contrasts the public reasons (productivity, security, union avoidance) and private reasons (curiosity, morality, voyeurism) why employers engage in workplace surveillance. He notes that most cases of employee dismissal are due to infractions of a lascivious nature, rather than for infractions due to simply wasting time or for personal use of electronic communications.

Corry and Nutz (2003), writing in the same issue, address the matter from management's perspective. They argue that employers might need to rely on surveillance practices because they may be held liable for criminal literature, such as hate or sexually harassing material, spread by employees at their workplace. The authors also delve into questions of the effects of electronic communications on questions of union activity in the workplace and employer interference. One important point they emphasize is that in the absence of specific language, employers have greater rights. "Even where such rules as an Internet/E-mail policy do not form part of the [collective] agreement, it is now generally conceded and was held in the case Crestbrook Forests Industries Ltd. (1993) that in the absence of specific language to the 
contrary in the agreement, the making of such rules or policies lies within the prerogative of management, and arbitrators have held this to be so whether or not an express management's rights clause exists reserving the right of management to direct and "manage" the work force" (p. 243). In general, there exists a significant gap in the literature that emphasizes and describes how Canadian unions are reacting to growing practices of surveillance. This paper seeks to fill that gap.

\section{METHODOLOGY}

The federal Department of Human Resources and Skills Development maintains the Negotech online database of current and historic collective agreements in Canada. The database is not collected based on a census method, but uses a statistical sampling method to obtain a stratified random sample of collective agreements (Roy, 2001). The initial sample was selected from the universe of bargaining units with more than 100 workers. All bargaining units of 2000 or more workers under provincial jurisdiction and all bargaining units of 200 workers or more under federal jurisdiction are sampled. For bargaining units of smaller sizes, there are different proportions of sampling, ranging from one in three to one in ten. The database includes a total of 5,495 English and French language collective agreements, signed under both federal and provincial jurisdiction.

In order to find collective agreements dealing with electronic surveillance, we searched the English-language collective agreements using the following search string "privacy or monitor or surveillance." We followed this with a search for "observation systems," a term which we knew to be used in some collective agreements. Within this initial subsample, we searched each individual collective agreement for clauses related specifically to electronic monitoring and surveillance. Of the several hundred collective agreements returned, 67 included collective agreement language directly related to electronic surveillance or monitoring in the workplace. The search was duplicated for the French-language collective agreements. The French-language database posed certain problems. For example, the verb "surveiller" and related nouns refer not only to issues of surveillance but also to supervision. Therefore, we modified the search to include the terms "surveillance électronique," "surveillance vidéo," "contrôl* électronique," and "contrôl* vidéo." (The asterisk serves as a "wildcard" character.)The French search yielded 9 collective agreements with relevant language. 
Because this study was most interested in electronic surveillance in the workplace, we rejected collective agreements that only included language on such issues as drug and alcohol testing, references to protection of privacy legislation or protection of individual records. Two collective agreements which required personal surveillance of workers engaged in cargo loading were rejected because the contract did not specify electronic surveillance.

\section{FINDINGS}

Out of 5,495 collective agreements, 4008 English and 1487 French, 76 (67 English and 9 French) contain language dealing with electronic surveillance in the workplace. Although this represents an undoubtedly small portion of collective agreements in Canada, it does indicate an improvement over the situation identified by Bryant in her 1995 study. In that study, she found virtually no response by unions to electronic surveillance practices in the workplace. Almost a decade later, some progress is being made. There are a number of reasons that could explain the limited response by Canadian unions. The relative decline of the industrial economy in which unions thrived has challenged the very survival of numerous unions in North America. The growth of a large temporary workforce and of companies like Walmart that are skilled in the use of new technologies to cuts costs have posed serious problems for traditional unions. Like their American counterparts Canadian unions have had to focus on fundamental issues like job security, wages, and organizing. Important as privacy is, and most unions recognize the problem that surveillance poses, unions have chosen to place it lower on the list of policy priorities. Furthermore, although this is changing, electronic surveillance and privacy have historically been applied to women workers such as telephone operators and data entry workers, whose limited power in unions has made it all the more difficult to give surveillance a more prominent place on the trade unions agenda. Electronic surveillance has been a feature of the North American workplace for some time, but its intensity and pervasive nature are relatively new. Yes, telephone operators had calls monitored electronically in the 1980 s, but now nearly every detail of a trucker's day is monitored as is nearly every web site an office worker surfs. Like many institutions, including governments, trade unions have just begun to absorb the enormity of the challenges posed by electronic monitoring, and it is little wonder that they have called on governments to shoulder the public policy responsibility of dealing with the problem. But the fact that some unions have decided to bargain the issue indicates a growing frustration with the pace of government attention. 
Among the unions that have succeeded in putting the issue into collective bargaining agreements, in both language groups, public sector unions predominated over private sector unions. Not unexpectedly, the overwhelming number of collective agreements with surveillance language were in the tertiary or service sector. This largely stems from the greater use of electronic communications and the greater importance of such to workplace measures.

\section{Table 1. Contracts Containing Surveillance Language by Public/ Private Sector}

\begin{tabular}{l|l|l} 
& French & English \\
\hline Private Sector & 6 & 29 \\
\hline Public Sector & 3 & 38
\end{tabular}

The two most represented national unions in the sample were the Canadian Auto Workers, who increasingly include service workers among their members and the Canadian Union of Public Employees. This is not surprising given that these unions are two of the three largest unions in Canada. University faculty unions made up the third largest group of unions with surveillance-related clauses.

Table 2. Contracts Containing Surveillance Language by Work Type

\begin{tabular}{l|l|l} 
& French & English \\
\hline Primary & & 2 \\
\hline Secondary & & 14 \\
\hline Tertiary & 9 & 51
\end{tabular}

The hypothesis that the collective agreements would be concentrated in the information sector of the economy is partially supported. The CAW and CUPE were the largest groups of unions with relevant language. The CAW collective agreements were, in large part in the auto and aerospace industries. Five of the ten CUPE collective agreements were concentrated in the post-secondary education sector. Taking those unions together with the seven faculty unions and two media unions, it is clear that information or language-oriented workplaces form a large part of the collective agreements with surveillance-related clauses. Five of the nine French-language collective agreements were in the university and media sectors. It was expected that there would have been a greater representation from the call centre industry. In fact, only two collective agreements covered call centre workplaces, one is a electrical power utility and the other is a telecommunications firm. Two explanations are likely for the predominance 
of the post-secondary sector. First, universities were among the first workplaces to adopt electronic communications in a widespread manner and so unions and management were likely forced to confront issues of surveillance in the workplace at an early stage. Second, unlike the call centre industry, Canadian universities are also largely unionized workplaces.

We identified four different types of surveillance language clause: low privacy protection, moderate privacy protection, high privacy protection and worker-friendly surveillance. The low protection category included cases where the employer was explicitly empowered to engage in surveillance activities or where the only restriction on surveillance was a matter of informing employees. Cases where surveillance practices were accepted but limits were sought (such as a halt to further expansion of surveillance activities) were assigned to the second category. Cases where surveillance practices were extremely limited, most often only to the prosecution of criminal offences, were assigned to the third category. Finally, surveillance language meant to be in the interest of worker safety and protection of their property were placed in the fourth.

Table 3. Contracts Containing Surveillance Language by Union

\begin{tabular}{l|c|c} 
& French & English \\
\hline Steelworkers & & 3 \\
\hline CAW & & 11 \\
\hline CUPE & 3 & 10 \\
\hline OPEIU & & 5 \\
\hline Hotel Workers & & 1 \\
\hline Transport Unions & & 3 \\
\hline Media Unions & & 2 \\
\hline Faculty Unions & & 7 \\
\hline Independent Unions & 3 & 6 \\
\hline SEIU & & 1 \\
\hline IAM & & 3 \\
\hline PSAC & & 3 \\
\hline CEP & 2 & 7 \\
\hline UFCW & & 4 \\
\hline Fédération Nationale des Communications & 1 & \\
\hline Provincial Public Sector Unions & & 1
\end{tabular}

Fifteen agreements were found to have the weakest protection against surveillance practices. The most dramatic case of the first is found in the agreement between Edmonton's Shaw Conference Center and the United 
Food and Commercial Workers Union which represents the support and catering staff. In their first collective agreement, awarded after a drawn-out strike, one finds the following clause:

\section{Management Rights}

3(1) EDE [Economic Development Edmonton] has the right to manage its business as it sees fit, including the right to utilize any surveillance methods without notice

Similarly, the agreement reached between Loomis Courier Services and the Canadian Auto Workers contained a clause which required the company to post warning signs:

\section{Letter of Agreement}

Electronic Surveillance Equipment

The following notice will be posted in all work places covered by the Collective Agreement: "Due to the nature of our business and occasional requests from customers, electronic surveillance equipment may be installed from time to time in the workplace."

It is understood that such equipment will not be installed in areas where employees are entitled to expect privacy, such a washrooms and locker rooms.

The United Food and Commercial Workers agreed to the following clause in agreements with both Canada Safeway and Overwaitea Foods:

Within the confines of the law, the Employer may use video cameras in almost any part of the store. The vast majority of employees have no need to be concerned and may be assured that common sense and discretion will prevail in choosing who is allowed access to any monitoring equipment or video tapes.

The reliance on the law is problematic as most provincial privacy legislation deals with the protection of personal information and access to government information as opposed to the protection of any individual space. Similarly labour legislation in Canada is generally silent on privacy issues. In short, at the low end of protection for privacy, unions have explicitly agreed to management use of surveillance practices with the only restrictions being the limits of the law or warnings to affected employees. 
Twenty-six collective agreements contained moderate protection against surveillance practices. For example, the United Steelworkers of America and an auto parts firm: "(d) No additional surveillance cameras will be installed in employee occupied areas." Presumably the union consented to the existing surveillance cameras in the workplace but won a halt to their spread. A second example is found in two collective agreements covering public libraries in Saskatoon and the Fraser Valley region. In those cases, the clause states: "The parties recognize that volume measurement may be necessary to obtain an objective evaluation of the level of production of a group, a section or an office. However, there shall be no electronic monitoring of an individual's work output for the purpose of evaluating performance." In this case, the union appears to be consenting to electronic monitoring in general, while attempting to restrict the scope of those practices from monitoring the work pace and productivity of individual workers.

Twenty-two agreements carried high protection against surveillance, most often in a written guarantee that video or electronic surveillance practices would not be used, except in narrowly-defined situations. For example, in a letter of intent explicitly dedicated to surveillance issues and supplementary to a collective agreement between a manufacturer and the Communications, Energy and Paperworkers, the union won the following written assurance: "This will confirm that the Company shall not use video security equipment to monitor employee work performance." The Canadian Union of Postal Workers has particularly strong language as well, which is not surprising, given the strength of the union, its history of militancy, and the close proximity of its members to valuable merchandise. One can understand simultaneously the desire of the employer to exercise strict measures to protect property and also the union's desire to restrict employers.

\subsection{Surveillance}

The watch and observation systems cannot be used except for the purpose of protecting the mail and the property of the State against criminal acts such as theft, depredation and damage to property. At no time may such systems be used as a means to evaluate the performance of employees and to gather evidence in support of disciplinary measures unless such disciplinary measures result from the commission of a criminal act.

It was noted above how some of the strongest language stems from agreements between unions as employers and the unions which represent 
their own employees. For example, the two agreements between CUPE, the Canadian Staff Union and the Office and Professional Employees International Union include the following:

\subsection{Electronic Monitoring, Surveillance, Employee Confidentiality}

1. Electronic monitoring and surveillance shall not be used for the purposes of individual work measurement of employees.

2. Surveillance cameras, any technology or systems capable of monitoring employees or their work and any other related equipment shall not be used in employee occupied areas without the knowledge of employees in the area. At no time shall video taping or any other form of electronic tracking or monitoring of employees, work output or attendance in or at a particular location be allowed for the purpose of random surveillance, audits or assessing discipline. At no time may such systems be used as a means to gather evidence in support of disciplinary measures. The Union shall be advised, in writing, of the location and purpose of all surveillance cameras and the reason for installation of such equipment.

Finally, there were five agreements (all English) that could be deemed to be "worker-friendly." This represents less than ten percent of the total sample and thus reinforces the idea that most surveillance practices tend to be in the interests of employers for productivity, security or disciplinary purposes. The protection of property and of the person were the two major reasons behind worker-friendly surveillance. For example, agreements between the Canadian Union of Public Employees and a casino in Calgary and between the CAW and Lear Corp. specified that the company would provide for electronic surveillance of the parking lot to protect staff vehicles. Similarly, an agreement between Nortel and the telecommunications workers of the CEP included the following: "For reasons of safety, when an employee is assigned to perform work in an isolated area and where it may not be possible for him to request assistance, the Company agrees to set up proper surveillance in order to provide help and/or assistance as may be necessary." Although surveillance practices can be put in place to protect the interests of employees, the overwhelming majority of collective agreement clauses on the matter involved unions attempting to restrict employers' use of electronic surveillance practices.

After studying all the collective agreements, it is apparent that there are several possible directions that collective agreements can take. For example: 
- Unions can allow surveillance practices and defer to management

- Unions can insist on signage in the workplace, informing employees and customers of the presence of surveillance technologies

- Unions can require that the employer inform the union about the introduction of surveillance practices

- Surveillance practices can be prohibited or prohibited save for criminal investigations.

- Unions can insist on surveillance technologies be put in place to protect workers health, safety and property

- Unions can prevent data gathered by electronic means from being used in productivity evaluation or criminal proceedings

- Unions can require that information above and beyond what was gathered by electronic means be used in any disciplinary or criminal proceeding

- Unions can require that employees be informed when they will be monitored electronically or unions can require the consent of individuals before surveillance can take place.

\section{CONCLUSION}

Bryant's article in 1995 sounded a decidedly pessimistic tone in evaluating the role that unions play in protecting worker privacy. Since that time, 76 collective agreements maintained in the federal government's database of Canadian collective agreements have enshrined clauses related to electronic monitoring and surveillance practices in the workplace. Out of the total of 5495 collective agreements maintained in the database, this number is very small. However, it does represent a first step. Clearly, the information sector, especially universities and public sector are most strongly represented in the group of collective agreements that formed our sample. And since this is the fastest growing sector of Canadian trade unionism, there is reason to expect growth in the number of collective agreements covering electronic surveillance. Equally important is that these collective agreements generally contained moderate to high degrees of protection for workers from excessive surveillance practices.

Surveillance practices are found in a wide range of industries and workplaces and, labour legislation is generally silent on privacy and surveillance issues. But, as is shown here, collective bargaining offers unions a wide range of options to structure, limit, influence or control such practices. 


\section{ACKNOWLEDGEMENTS}

We would like to thank The Surveillance Project at Queen's University whose grant from the Social Sciences and Humanities Research Project provided financial assistance for the research. We would also like to acknowledge the research assistance of Laura Glithero, an undergraduate student at Queen's. Thanks also to Professor Catherine McKercher, Carleton University, for her valuable comments and to participants at the June 2005 conference on Landscapes of ICT and Social Accountability in Turku, Finland for their helpful suggestions.

\section{REFERENCES}

American Civil Liberties Union (1998), Through the keyhole: privacy in the workplace..

Aranda, J. T. (2002), Information technology and worker's privacy: the role of workers' representatives, Comparative Labour Law Policy Journal, 23 (2), 533-549.

Bennett, C. (2003), Surveillance, employment and location: regulating the privacy of mobile workers in the mobile workplace, paper prepared for a conference on The Ethics of Workplace Privacy, Sigtuna, Sweden, November 10-11, 2003.

Bloom, E. M., Schachter, M., and Steelman, E. H (2003), Competing interests in the post-911 workplace: the new line between privacy and safety, William Mitchell Law Review, 29 (3), 897-920.

Bryant, S. (1995), Electronic surveillance in the workplace, Canadian Journal of Communication, Vol. 20 (4), 505-522.

Corry, D. J., and Nutz, K.E. (2003), Employee email and internet use: Canadian legal

issues, Journal of Labor Research, 24 (3), 233-256.

Electronic Privacy Information Center (2004), Workplace privacy, online at http://www.epic.org/privacy/workplace/ accessed 31.01.2005

European Industrial Relations Observatory (2003), New technology and respect for privacy at the workplace, European Foundation for the Improvement of Living and Working Conditions.

Finlay, P. and McKinlay, A. (2003), Surveillance, electronic communications technologies and regulation, Industrial Relations Journal, 34 (4), 305-318.

Hazard's Magazine (2004), Stop snooping, online at http://www.hazards.org/privacy/ accessed 31.01.2005

Head, S. (2003), The new ruthless economy: work and power in the digital age. Oxford

University Press.

International Labour Organization (1997), Protection of workers personal data. ILO.

King, Nancy J. (2003), Electronic monitoring to promote national security impacts workplace privacy, Employee Responsibilities and Rights Journal, 15, (3), 127-147.

Lyon, D. (1994), The electronic eye: the rise of surveillance society, U. of Minnesota Press.

Lyon, D. (2001), Surveillance society: monitoring everyday life, Open University Press.

Marx, G. (2003), A tack in the shoe: neutralizing and resisting the new surveillance, Journal of Social Issues, 59, 2, 369-390.

Nolan, D. (2003), Privacy and profitability in the technological workplace, Journal of Labor Research, 24 (2), 207-231. 
Parenti, C. (2003), The soft cage: surveillance in America from slavery to the war on terror. Basic Books.

Rotenberg, M. and Laurant, C. (2004), Privacy and human rights 2004: an international survey of privacy laws and developments. Electronic Privacy Information Center.

Roy, J. (2001), Information on collective bargaining: moving from a census to a sample approach." Workplace Gazette, 3 (2), 12-20.

Rule, J. (1996), High-tech workplace surveillance: what's really new? in D. Lyon and E. Zureik (eds.), Computers, surveillance and privacy, University of Minnesota Press.

Shane, P. (2004), Democracy Online: The Prospects for Democratic Renewal Through the Internet. Routledge.

Townsend, A.M. \& Bennett, J. T. (2003), Privacy, technology, and conflict: emerging issues and action in workplace privacy, Journal of Labor Research, 24 (2), 195-205.

Wallace, P. (2004), The internet in the workplace: how new technology is transforming work, Cambridge University Press. 